Click www.researchjournal.co.in/online/subdetail.html to purchase.

INTERNATIONAL JOURNAL OF PLANT PROTECTION

- ISSN-0974-2670 | Visit us : www.researchjournal.co.in

\title{
Management of powdery mildew of cluster bean through fungi toxicants
}

\author{
Arun R. Sataraddi* and Jitendra Kumar S. Hilli ${ }^{1}$
}

Department of Plant Pathology Agriculture Research Station, Bagalkot (Karnataka) India ${ }^{1}$ Seeds Unit, University of Agricultural Sciences, Dharwad (Karnataka) India

\section{Aritcle Info}

Received : 29.07 .2020

Revised : 12.09 .2020

Accepted : 25.09 .2020

KEY WORDS : Cluster bean, leveillula taurica, systemic fungicides, In vitro, In-vivo

*Corresponding author:

Email : arunsataraddi@gmail.com

\begin{abstract}
Leveillula taurica causes severe powdery mildew on all aerial parts of cluster bean plant. The objective of the present work was to identify potential methods for managing cluster bean powdery mildew through fungicides. Field trials were conducted during Kharif 2019 and 2020 to evaluate the efficacy fungicides. Nine systemic fungicides were tested both under in-vitro and in-vivo conditions against cluster bean powdery mildew disease. In vitro evaluation of fungicides revealed that complete inhibition of conidial germination was observed in all systemic fungicides at 0.1 per cent concentration. However, under field conditions, penconazole at 0.05 per cent was found to be best fungicide which recorded least incidence 3.66 per cent followed by hexaconazole (5.83\%) and propiconazole $(6.83 \%)$.
\end{abstract}

How to view point the article : Sataraddi, Arun R. and Hilli, Jitendra Kumar S. (2020). Management of powdery mildew of cluster bean through fungi toxicants. Internat. J. Plant Protec., 13(2) : 207-210, DOI : 10.15740/HAS/IJPP/13.2/207-210, Copyright@ 2020: Hind Agri-Horticultural Society. 